NOTES

\title{
TRADE-MARK INFRINGEMENT: THE POWER OF AN AMERICAN TRADE-MARK OWNER TO PREVENT THE IMPORTATION OF THE AUTHENTIC PRODUCT MANUFACTURED BY A FOREIGN COMPANY
}

Section 42 of the Lanham Trade-Mark Act ${ }^{1}$ and Section 526 of the Tariff Act ${ }^{2}$ authorize American trade-mark owners to prohibit the importation of merchandise ${ }^{3}$ bearing a trade-mark which infringes a registered United States mark. 4 These provisions are enforced by the Bureau of Customs, ${ }^{5}$ whose agents stop such goods at the border unless the registrant of

1. "[N]o article of imported merchandise . . . which shall copy or simulate a tridemark registered in accordance with the provisions of this Act ... shall be admitted to entry at any customhouse of the United States." 60 Srar. 440 (1946), 15 U.S.C. §1124 (1952), re-enacting $\$ 27$ of the Trade-Mrark Act of 1905, 33 STAr. 730.

2. Section 526 omits the phrase "copy or simulate" and states that "it shall be unlawful to import into the United States any merchandise of foreign manufacture if such merchandise ... bears a trade-mark owned by a citizen of, or by a corporation or association created or organized within the United States, and registered in the Patent Office by a person domiciled in the United States." 42 STAT. 975 (1922), 19 U.S.C. §1526 (1952).

3. Merchandise includes goods brought into the United States for personal use Sturges v. Clark D. Pease, Inc., 48 F.2d 1035 (2d Cir. 1931) (second-hand forcign automobile).

4. Only trade-marks registered under the Trade-Mrark Act of 1905 or on the principal register of the Lanham Act can be used to prevent importation. A supplemental register for certain weaker trade-marks was established in 1920. 60 STAт. 435 (1946), 15 U.S.C. $\$ 1091$ (1952). However, trade-marks registered only on these supplementary registers cannot be employed under $\$ \$ 42$ and 526. 60 STAT. 436 (1946), 15 U.S.C. $\S \S 1094,1096$ (1952); 19 C.F.R. $\$ 11.14$ n.16 (1954) (Customs Regulations).

5. The trade-mark must first be registered in the Patent Office. The initial proceeding is ex parte and registration is only refused if the mark is clearly unregisterable. After this initial step the registration may be opposed. The rights of opposing parties are then determined inter partes by the Examiner of Interferences and, on appeal, by the Commissioner of Patents. See Derenberg, The Patent Office as Guardian of the Public Interest in Trade-Mark Registration Proccedings, 14 LAW \& Contras. Pron. 288 (1949).

The trade-mark owner must file his registration certificate with the Treasury Department if he wants infringing products stopped by customs officials. 19 C.F.R. $\S 11.15$ (1954). The importer who then desires to bring his product into the United States over the objection of the registered trade-mark owner can: 1) proceed in a cancellation suit in the Patent Office; 2) ask a district court to restrain the collector of customs from stopping his goods; and 3) ask a district court to enjoin the trade-mark ouner from refusing permission. When suing in a district court, the importer can contend that his mark does not iniringe the registered trade-mark or he can try to prove that the object- 
the American trade-mark consents to importation. ${ }^{b}$ American trade-mark owners have used the statutes to exclude spurious wares and cheap imitations. ${ }^{7}$ And, by registering the trade-marks of foreign producers in their own names, ${ }^{8}$ American affiliates of foreign manufacturers have also prevented the importation of authentic products by anyone other than themselves. ${ }^{9}$

Three decades ago, in Bourjois v. Katzel, ${ }^{10}$ the Supreme Court departed from earlier cases and held that a trade-mark could be infringed by the importation and sale of the authentic product. ${ }^{11}$ A French manufacturer of face powder sold plaintiff its American business including the trade-marks "Bourjois" and "Java."12 Plaintiff continued to import the French powder and to sell it in boxes similar to the French ones. Defendant imported the identical powder and sold it in the original French boxes. The court held that this infringed plaintiff's trade-mark and it enjoined defendant from importing and selling the genuine powder. The court reasoned that since

ing trade-mark owner does not have a valid mark. Croton Watch Co. v. Laughlin, 208 F.2d 93 (2d Cir. 1953); Coty v. Le Blume Import Co., 293 Fed. 344 (2d Cir. 1923). Accord, Holland v. C. \& A. Import Corp., 8 F. Supp. 259 (S.D.N.Y. 1934) (but defendant denied relief due to misrepresentation).

6. 42 Stat. 975 (1922), 19 U.S.C. $\$ 1526$ (1952) (§526); 19 C.F.R. $\$ 11.14$ (1954) (implementing $\$ \$ 526 \& 42$ ). The prohibition does not apply if the infringing mark is removed or completely obliterated prior to importation. 19 C.F.R. $\$ \$ 11.14,11.17$ (1954).

7. See, e.g., Coty v. Le Blume Import Co., 293 Fed. 344 (2d Cir. 1923) (infringing perfume) ; Etermit, Inc. v. J.J. Clarke Co., 18 F.2d 607 (E.D. La. 1927) (import of inferior asbestos shingle). A recent dictum has doubted the efficacy of the protection against tourist imports. Bulova Watch Co. v. Steel, 194 F.2d 567, 572 (5th Cir. 1952).

8. Section 526 requires that the trade-mark be registered by a person domiciled in the United States. See note 2 supra.

9. See Bourjois v. Aldridge, 263 U.S. 675 (1923), deciding questions certificd in 292 Fed. 1013 (2d Cir. 1922) (based on $\$ 27$ of the Trade-Mark Act of 1905, 33 STAT. 730, now $\S 42$ of the Lanham Act); Sturges v. Clark D. Pease, Inc., 48 F.2d 1035 (2d Cir. 1931) (based on $\$ 526$ ).

The registration of a trade-mark may be aimed primarily at getting the advantage of this power to exclude. See, e.g., Hamilton Watch Co. v. Hamilton Chain Co., $43 \mathrm{~F}$. Supp. 85, 89 (D.R.I. 1942) (registration to prevent threatened importation from Switzerland).

10. 260 U.S. 689 (1.923), reversing 275 Fed. 539 (2d Cir. 1921), and affirming 274 Fed. 856 (S.D.N.Y. 1920).

11. A series of decisions had held that the importation and sale of genuine articles could not constitute trade-mark infringement because the purpose of tradc-marks is to denote authenticity. See, e.g., Apollinaris Co. v. Scherer, 27 Fed. 18 (C.C.S.D.N.Y. 1886) ; Hunyadi Janos Corp. v. Stoeger, 285 Fed. 861 (2d Cir. 1922); Fred Gretsch Mfg. Co. v. Schoening, 238 Fed. 780 (2d Cir. 1916) (interpreting $\$ 27$ of the Trade. Mark Act of 1905, 33 Stat. 730).

The Supreme Court did not refer to the former decisions but it is generally assumed they are overruled, especially since the reversed court of appeals decision quoted them extensively. Bourjois v. Katzel, 275 Fed. 539 (2d Cir. 1921). But comparc Annot., 26 A.L.R. 570 (1923), with California Wine \& Liquor Corp. v. William Zakon \& Sons, 297 Mass. 373, 8 N.E.2d 812 (1937).

12. The sale price was $\$ 400,000$. Bourjois v. Katzel, 274 Fed. 856, 857 (S.D.N.Y. $1920)$. 
the French manufacturer could not use the trade-marks in the United States after having sold them to the plaintiff, the defendant should not be allowed to use them either. ${ }^{13}$ It also stated that defendant's use of the marks could harm plaintiff's reputation because the public associated the face powder with the plaintiff rather than with the foreign manufacturer. ${ }^{14}$

The government recently began taking steps to restrict Katzel to those situations in which the American trade-mark owner is independent of the foreign producer. As a first step, the Treasury Department changed the customs regulations to provide that a trade-mark on imported goods does not infringe a recorded American mark if both marks are owned by relaled companies. ${ }^{15}$ An American concern is related to a foreign manufacturer if

13. Mr. Justice Holmes supported this conclusion only by analogy to patent law. But the exclusive privilege granted by a patent right depends upon the usefulness and novelty of the invention, 66 STAT. 797, 35 U.S.C. $\$ 101$ (1952), and is limited to a period of seventeen years. 66 STAT. 804, 35 U.S.C. $\$ 154$ (1952). Trade-mark protection, on the other hand, is unlimited in time and does not depend upon any new or useful contribution by the owner of the mark. Moreover, both Congress and the courts have been careful to differentiate between the protection granted to patents and to trade-marlss. See, e.g., S. REP. No. 1333, 79th Cong., 2d Sess. 3-4 (1946); United Drug Co. v. Rectanus, 248 U.S. 90, 97-98 (1918).

The patent analogy is further weakened by Mr. Justice Holmes' subsequent opinion in Prestonettes, Inc v. Coty, 264 U.S. 359, 368 (1924), where he drew a sharp distinction between trade-marks and copyrights, despite the similarity of copyrights to patents.

14. Mr. Justice Holmes subsequently declared that this was the basis of the Katzel decision. Prestonettes, Inc. v. Coty, 264 U.S. 359, 368 (1924). Public association of the face powder with the importer rather than the foreign manufacturer is dubious because American importers of toilet goods do everything possible to associate their products with the French origin of the goods. Furthermore, since the product was genuine, no consumer was deceived when purchasing "Bourjois" toiletries.

If the Katzel decision is based on the identification of the products with the importer rather than with the foreign manufacturer, American courts have never clearly explained what is necessary for such a showing. An analogy may be found in the English action for "passing off" which requires a showing that the trade-mark be associated with the dealer. The English cases hold the test to be some feature which indicates that the dealer guarantees the quality of the product. C.G. Vokes Itd. v. E.J. Evans, 49 R.P.C. 140 (1932) (examination of product as to quality by dealer); Imperial Tobacco Co. v. Bonnan, 41 R.P.C. 441 (1924) (reputation was that of manufacturer rather than of distributor because distributor did not select or guarantee product); Dental MIfg. Co. v. C. de Trey \& Co., 29 R.P.C. 617 (1912) (relief denied because no change in get-up or other identification of product with distributor in eyes of consumer). And compare Perry v. American Hecolite Denture Corp., 78 F.2d 556 (8th Cir. 1935) (distributor selected, processed, and wrapped product; held to have get-up of its own superior to original product), with California Wine \& Liquor Corp. v. William Zakon \& Sons, 297 Mass. 373, 8 N.E.2d 812 (1937) (sale of genuine whiskey under different but infringing trade-mark by another distributor held unfair competition).

15. 19 C.F.R. $\$ \$ 11.14-17$ (1954). The new regulations went into effect December 17, 1953. Important Changes in the Custons Regulations Concerning Recordation of Trade-Marks and Trade Names, 44 TRADE-MIARK REP. 131 (1954).

One commentator has expressed doubt as to the validity of the new regulations in view of $\$ 526$. Derenberg, The Seventh Ycar of Administration of the Lanham TradcMark Act of 1946, 44 TRADE-MAARE REP. 991, 997-98 (1954). 
it controls, or is controlled by, the overseas firm with respect to the trademarked product. ${ }^{16}$ Secondly, legislation was introduced in Congress to prevent affiliated concerns from invoking the import prohibitions. ${ }^{17}$ Affiliated concerns include not only related companies but also firms which are licensed to use the trade-mark as agent or distributor. ${ }^{18}$ Finally, the Department of Justice filed complaints charging four American toilet goods concerns with monopolizing and attempting to monopolize the importation and sale of toilet goods bearing their trade-marks. ${ }^{19}$ The Government contends that defendants' utilization of sections 42 and 526 violates the Sherman Act because

16. Section 45 of the Lanham Act defines a related company as any person, partnership, association, or corporation which legitimately controls, or is controlled by, the registrant or applicant for registration in respect to the nature and quality of the goods in connection with which the mark is used. 60 STAT. 443 (1946), 15 U.S.C. \$1127 (1952).

This definition supplements $\S 5$ of the Lanham Act, which permits the use of trademarks by related companies if the public is not deceived. 60 STAT. 429 (1946), 15 U.S.C. $\$ 1055$ (1952). For various interpretations of $\$ 5$, see Shniderman, Trade-Mark Licensing-A Saga of Fantasy and Fact, 14 LAw \& Contenc. Pron. 248 (1949); Taggart, Trade-Marks and Related Companies: A New Concept in Statutory Trade-Mark Lane, id. at 234; Timberg, Trade-Marks, Monopoly, and the Restraint of Compctition, id. at $323,353-57$.

17. There is confusion both as to the form and the import of the proposed legislation. The Senate proposal would repeal $\$ 526$ and so amend $\$ 42$ that " $a$ foreign mark which is identical with a mark recorded ... shall not be deemed to copy or simulate the said recorded mark when used by a person having a branch-factory, parent-subsidliary, agency, licensee, partnership or similar relationship with the owner of the registration." S. 2540, 83d Cong., 2d Sess. 36 (1954). Articles such as tourist imports which can be entered free of duty could not be stopped at the border. Id. at 36-37.

The House version took the form of amending $\S 526$ and repealing $\S 42$. H.R. 9476, tit. V, 83d Cong., 2d Sess. (1954).

The modifications were proposed by the Treasury with the concurrence of other interested departments. See letter from Deputy Atty. Gen. Rogers to Senator Langer, April 16, 1954, reprinted in Hearing before a Subcommittee of the Sentate Committec on the Judiciary on S. 2540, 83d Cong., 2d Sess. 93-95 (1954); Letter from Asst. Sec'y of State Morton, April 28, 1954, reprinted in Hearing, supra at 95-97; S. REP. No. 2266, 83d Cong., 2d Sess. 9 (1954).

The State Department letter stated that the proposed change is "already considered implicit in existing law" by the Treasury Department. Hearing, supra at 96 . However, the scope of the legislative amendment, which affects all affiliated companies, is considerably broader than the customs regulation, which only affects related concerns.

Both House and Senate amendments have now been withdrawn so the Treasury Department can "look further into the matter." Letter from Representative Joln Byrne" to the Yale Law Journal, dated Nov. 15, 1954, on file in Yale Law Library; H.R. 10009, 83d Cong., 2d Sess. (1954) ; 100 Cong. Rec. 13383 (Aug. 11, 1954). And see Derenberg, The Seventh Year of Administration of the Lanham Trade-Mark Act of 1946, 44 Tradt:MARK REP. 991, 992 (1954), referring to strong opposition by affected industrics.

18. See note 17 supra.

19. See complaints in United States v. Guerlain, Inc., Civil No. 93-267, S.D.N.Y., May 28, 1954; United States v. Parfums Corday, Inc., Civil No. 93-268, S.D.N.Y., May 28, 1954; United States v. Lanvin Parfums, Inc., Civil No. 93-269, S.D.N.Y., May 28, 
defendants are not independent of the foreign manufacturers of their products. ${ }^{20}$

Trade-mark protection is a judicially developed ${ }^{21}$ and legislatively supported ${ }^{22}$ common law right ${ }^{23}$ which seeks to preserve three distinct but often conflicting interests:24 1) the consumer's desire to get particular goods; 2)

1954; United States v. Empro Corp., Civil No. 93-270, S.D.N.Y., Mray 28, 1954. And see CCH TRADE REg. Rep. II 66,128 (1954).

The Empro Corporation (American "Ientheric") agreed to a consent decree giving the government the relief it desired. United States v. Empro Corp., Civil No. 93-270, S.D.N.Y., May 28, 1954, CCH Trade Reg. ReP. (1954 Trade Cas.) 【67,778 (1954). Empro agreed to the consent decree because it decided for financial reasons, to dispose of its French and English corporations within 120 days. The consent decree was negotiated without any admissions of fact. Statement for defendant before Edlestein, J., Miay 28, 1954, on file, S.D.N.Y.

20. Defendants are charged with violating $\$ 2$ of the Sherman Act, 26 STAT. 209 (1890), 15 U.S.C. $\$ 1$ (1952).

21. For the judicial development of trade-marks from merchants' marlis (indicia of ownership) and production marks (indicia of origin of source of manufacture), see Schechter, Histodicai Foundations of Trade-M1ark LAw (1925). And see Franl, J., in Standard Brands v. Smidler, 151 F.2d 34, 37-43 (2d Cir. 1945) (concurring opinion).

22. It is generally stated that trade-mark statutes merely grant procedural rather than substantive rights. See, e.g., Griesedieck Western Brewery Co. v. Pcople's Brewing Co., 149 F.2d 1019 (Sth Cir. 1945) ; Ph. Schneider Brewing Co. v. Century Distilling Co., 107 F.2d 699 (10th Cir. 1939). But cf. Brooks Bros. v. Broolis Clothing, 60 F. Supp. 442 (D. Cal. 1945) ("the law of trade-marks is purely statutory"), aff'd fer curiam, 158 F.2d 798 (9th Cir.), cert. denied, 331 U.S. 824 (1947). And comfore majority opinion (registration confers only procedural advantages), tuil/s dissent (the Lanham Act broadens both registrability of trade-marks and remedies for infringement) in Best \& Co. v. Miiller, 167 F.2d 374 (2d Cir.), cert. denied, 335 U.S. 818 (1948).

Although it has been stated that the constructive notice section of the Lanham Act creates substantive rights, the cases do not so hold. Compare Derenberg, The Palcnt Office as Gutardian of the Public Intercst in Trade-1Yark Registration Procecdings, 14 LAW \& Conteas. Pros. 288 (1949), with Willson v. Graphol Products Co., 18s F.2d 498 (C.C.P.A. 1951). And see B.B. Pen Co. v. Brown \& Bigelow, 92 F. Supp. 272 (D. Minn. 1950), aff'd. 191 F.2d 939 (Sth Cir. 1951), cert. denied, 343 U.S. 920 (1952).

Even if it has not granted any substantive rights, Congress is confident it has the power to do so. S. Rep. No. 1333, 79th Cong., 2d Sess. 5-6 (1946). State legislatures have also assumed they can make substantive modifications of trade-mark rights. See, e.g., the statutory enactment of "dilution" of distinctive quality of a trede-marl as a test of infringement. N.Y. GeN. Bus. LAw. \$361-a; MAss. ANs. LAws c 110, \$7A (1954).

23. Southern v. How, Popham 143, 79 Eng. Rep. 1243 (1656?) ; Thompson v. Winchester, 36 Mass. (19 Pick) 214 (1837); Taylor v. Carpenter, 3 Story 458, 23 Fed. Cas. 742 , No. 13784 (C.C.D. Mass. 1844 ).

24. Conflict is particularly sharp in deciding between the importance of private injury to a particular plaintiff and the importance of injury to the public interest. Two commentators polarize the attitudes. Compare 1 Callsyas, Unfais Cosspermo: and Trade-Marks 60 (2d ed. 1950), with Zlinkoff, Mionopoly Versts Competition: Significant Trends in Patent, Anti-Trust, Trade-Mark, and Unfair Competition Suits, 53 Yale L.J. 514, 529 (1944). And see Aunt Jemima Mills Co. v. Rigney \& Co., 234 Fed. \&04, 806 (E.D.N.Y. 1916) (both conduct calculated to deceive the public and private loss of 
the trade-mark owner's interest in maintaining the good will of his business; and 3 ) the public policy in favor of free competition. None of these goals is furthered when sections 42 and 526 are used by related concerns to prevent price competition from firms which are willing to sell the authentic product at prices lower than those set by the owner of the domestic trade-mark.

Trade-marks enable purchasers to identify the goods of specific manufacturers. ${ }^{25}$ They symbolize the quality of particular products and the satisfaction such products have provided in the past. ${ }^{26}$ Therefore, to protect consumers from being deceived into purchasing inferior goods, courts prohibit the sale of articles which bear marks likely ${ }^{27}$ to mislead reasonable ${ }^{28}$ purchasers as to the ultimate source of the merchandise. ${ }^{20}$ However, if the American registrant of the trade-mark of a foreign manufacturer is denied the right to invoke sections 42 and 526 against the importation of the wares of the foreign producer, there is no likelihood of such deception. ${ }^{30}$ The con-

plaintiff essential elements); Eastern Wine Corp. v. Winslow-Warren, Ltd., 137 F.2d 955, 959 (2d Cir. 1943) ("the protection of the interest of consumers is an ever-present factor in considering the allowable extent of monopolies in trade names"); Gencral Baking Co. v. Gorman, 3 F.2d 891, 893 (1st Cir. 1925) ("the plaintiff is acting, not only in his own interest, but in the public interest").

25. See, e.g., National Nu Grape Co. v. Guest, 164 F.2d 874 (10th Cir. 1947); Pflugh v. Eagle White Lead Co., 185 Fed. 769, 771 (3d Cir. 1911); Angstein v. Saks, 69 F. Supp. 547 (N.D. Cal. 1946).

26. E.g., Mishawaka Rubber \& Woolen Mfg. Co. v. S.S. Kresge Co., 316 U.S. 203, 205 (1941); Avrick v. Rockmont Envelope Co., 155 F.2d 568 (10th Cir. 1946) ; Shredded Wheat Co. v. Humphrey Cornell Co., 250 Fed. 960 (2d Cir. 1918).

27. There is no requirement of actual confusion. Standard Brands v. Eastern Shorc Canning Co., 172 F.2d 144 (4th Cir. 1949), cert. denied, 337 U.S. 925 (1949); La Touraine Coffee Co. v. Lorraine Coffee Co., 157 F.2d 115 (2d Cir. 1946). Compare Vick Chemical Co. v. Thomas Kerfoot \& Co., 80 F.2d 73 (C.C.P.A. 1935) (unlikelihood of confusion between "Vicks," "Vapex," and "Vaporub" not overcome by showing of actual confusion), with Rytex Co. v. Ryan, 126 F.2d 952 (7th Cir. 1942) (proof of actual confusion almost always required). But see Schechter, The Rational Basis of TradeMark Protection, 40 Harv. L. REv. 813, 825 (1927) (actual confusion necessary).

28. Independent Nail \& Packing Co. v. Stronghold Screw Prod., 205 F.2d 921 (7th Cir. 1953); Best \& Co. v. Miller, 167 F.2d 374, 376 (2d Cir. 1948); La Touraine Coffee Co. v. Lorraine Coffee Co., 157 F.2d 115, 117 (2d Cir. 1946). Cf. Stork Restau. rant, Inc. v. Sahati, 166 F.2d 348, 359 (9th Cir. 1948); Florence Mfg. Co. v. J.C. Dowd \& Co., 178 Fed. 73, 75 (2d Cir. 1910).

29. Although arguments have been made for both its extension and its restriction, the test of confusion of ultimate source has been accepted by the courts and by Congress. Yale Electric Corp. v. Robertson, 26 F.2d 972 (2d Cir. 1928); National Fruit Product Co. v. Dwinell-Wright Co., 47 F. Supp. 499 (D. Mass. 1942) (a very careful analysis of the test of confusion of source by Judge Wyzanski), aff'd, $140 \mathrm{~F} .2 \mathrm{~d} 618$ (1st Cir. 1944); 60 Stat. 437 (1946), 15 U.S.C. $\$ 1114$ (1) (a) (1952). Comparc Brown, Advertising and the Public Interest: Legal Protection of Trade Symbols, 57 YaLE L.J. 1165 (1948), avith Callman, Trade-Mark Infringement and Unfair Competition, 14 LAW \& Contrem. Prob. 185 (1949).

30. This conclusion is implicit in the decisions which held that the trade-mark on a genuine product does not infringe the rights of the trade-mark owner because the consuming public is not deceived when it receives the authentic article. See note 11 supro. 
sumer is assured of the same product made by the same manufacturer whether the article is bought from the American branch of the French producer or from a competing independent importer.

The good will threatened by trade-mark infringement is usually defined in terms of reputation. ${ }^{31}$ The threat to the owner's reputation lies in the possibility that the infringer will put out an inferior product. 32 Public confusion as to the source of the inferior article would then lead to consumer ill will directed against the producer of the authentic commodity. ${ }^{33}$ But there is no possibility of this occurring when the "infringing" importer is bringing in the identical product being distributed by the domestic registrant. 34

It has been argued that good will should also include the profit expectations of the trade-mark owner. ${ }^{35}$ The forfeiture by an international concern of the exclusive right to sell in the American market certainly frustrates its trade expectations. ${ }^{36}$ But expectations should not become self-perpetuating merely because their supporters label them "good will" or "property."

31. Bourjois v. Katzel, 260 U.S. 689, 692 (1922); 1 Nars, UnfaIR Cos.retrtrosi Ast Trade-Marks 73 (4th ed. 1947); Rogers, The Lanham Act and the Social Funetion of Trade-lifarks, 14 Law \& Contear. ProB. 171, 176 (1949).

32. See, e.g., Triangle Publications v. Rohrlich, 167 F.2d 969, 972 (2d Cir. 1948); Greyhound Corp. v. Goberna, 128 F.2d 806 (5th Cir. 1942); Scriven v. North, 134 Fed. 366, 372-73 (4th Cir. 1904). There is no need to prove the infringing product is inferior because there is a presumption to that effect. Peninsular Chemical Co. v. Levinson, 247 Fed. 658 (6th Cir. 1917) ; Jacob Ruppert $v$. Knickerbocker Food Specialty Co., 295 Fcd. 381, 383 (E.D.N.Y. 1923).

33. As Judge L. Hand pointed out, if someone uses a merchant's trade-mark "he borrows the owner's reputation, whose quality no longer lies within his own control." Yale Electric Corp. v. Robertson, 26 F.2d 972, 974 (2d Cir. 1928). And see Standard Brands v. Smidler, 151 F.2d 34, 37 (2d Cir. 1945); Time, Inc. v. Ultem Pubs., 96 F.2d 164, 165 (2d Cir. 1938).

34. The importation of authentic goods by tourists and by commercial importers mas harm the reputation of the trade-mark owner to the extent that his reputation is based on "snob appeal." Such appeal, based on the exclusiveness rather than the quality of the product, has received some judicial recognition. See, c.g., Bentun v. FTC, 130 F.2d 254 (2d Cir. 1942) (cease and desist order from calling own process "engraving") ; FTC v. Algoma Lumber Co., 291 U.S. 67, 78 (1933).

35. The argument is that because trade-marks induce consumer purchasing, the owner of a trade-mark has a vested right in his expectation of future trade. Sce, c.g., Callman, Unfair Competition without Competition? The Imporlance of the Property Concept in the Law of Trade-Marks, 95 U. PA. L. Rev. 443 (1947); Schechter, The Rational Basis of Trade-11ark Protection, 40 HARv. L. REv. 813 (1927).

36. In its action against the toilet goods concerns, the Government secks to bring about just such a "frustration." The Government claims that these concerns have been able to maintain noncompetitive retail selling prices which are substantially higher than those prevailing in foreign countries. See complaints cited note 19 sutpra; Department of Justice Press Release, May 28, 1954.

37. Some courts have called trade-marks a property right. E.g., The Trade Mark: Cases, 100 U.S. 82, 92 (1879) ; Bayer Co. v. Shoyer, 27 F. Supp. 633, 636 (E.D. Pa. 1939). But see Loughran v. Quaker City Choc and Confect. Co., 286 Fed. 694, 697 
When expected profits are based on the prior enforcement of a special privilege, they should be maintained only if that privilege is socially justified. ${ }^{38}$ There is no such justification for the use of sections 42 and 526 by related concerns. The employment of these sections by related firms protects neither the reputation of the trade-mark owner nor the authenticity of its products. It merely results in higher prices to consumers.

Despite perceptive arguments that trade-marks are monopolistic grants, ${ }^{\text {a0 }}$ most courts ${ }^{40}$ and Congress ${ }^{41}$ have concluded that protection of trade-marks

(E.D. Pa. 1923). The question is generally skirted by calling the trade-mark a symbol of good will and as such a property right only in a qualified sense. Hanover Star Milling Co. v. Metcalf, 240 U.S. 403, 413-15 (1916) ; Beech-Nut Packing Co. v. P. Lorillard Co., 273 U.S. 629, 632 (1927). And see 3 Restatement, Torts $\$ 717$, comment $a$ (1938).

The limited nature of the "property" right is emphasized by the rule that a trade-mark cannot be transferred in gross. United Drug Co. v. Rectanus Co., 248 U.S. 90 (1918); 3 Restatement, TORTS § 755 (1938).

38. This was recognized by an early decision which pointed out that although an exclusive right is certainly valuable, the fact that it would have money value if it existed is not a conclusive reason for recognizing the right. Chadwick v. Corell, 151 Mass. 190, 193, 23 N.E. 1068, 1069 (1890). And Felix Cohen has shown the circularity of basing legal protection on economic value when the economic value of a trade-mark depends upon the extent of its legal protection. Cohen, Transcendental Nonsense and the Funttional Approach, 35 CoLunr. L. Rev. 809, 814-17 (1935).

39. Judge Jerome Frank has repeatedly stressed that the legal protection of trademarks creates judge-made monopolies. E.g., Standard Brands v. Smidler, 151 F.2d 34, 37 (2d Cir. 1945) (concurring opinion) ; Triangle Publications Inc. v. Rohrlich, 167 F.2d 969, 980-82 (2d Cir. 1948) (dissenting opinion); Eastern Wine Corp. v. Winslow-Warren Ltd., 137 F.2d 955 (2d Cir. 1943).

Other judges have recognized the monopolistic implications of trade-mark protection but have been less convinced by the monopoly approach. See, e.g., Wyzanski, J., in National Fruit Product Co. v. Dwinell-Wright Co., 47 F. Supp. 499, 506 (D. Mass. 1942) ; Clark, J., in La Touraine Coffee Co. v. Lorraine Coffee Co., 157 F.2d 115, 118 (2d Cir. 1946) ; Rogers, J., in Le Blume Import Co. v. Coty, 293 Fed. 344, 349 (2d Cir. 1923).

Commentators stressing the creation of monopolies through trade-mark protection in. clude Chamberlin, The Theory of Monopolistic Competition 270-74 (6th ed. 1950); Diggins, Trade-Marks and Restraints of Trade, 32 Geo. L.J. 113 (1944); Timberg, Trade-Marks, Monopoly and the Restraint of Competition, 14 LAw \& ConTEM. Pros. 323 (1949). But see Taggart, Trade-Marks: Monopoly or Competition?, 43 Mrcu. L. Rev. 659 (1945); Wright, Some Pitfalls of Economic Theory as a Gutide to the Lawe of Competition, 37 VA. L. REv. 1083 (1951.).

40. United Drug Co. v. Rectanus Co., 248 U.S. 90, 97-98 (1918); Louchran v. Quaker City Choc. \& Confect. Co., 286 Fed. 694, 697 (E.D. Pa. 1923); Independent Baking Powder Co. v. Boorman, 130 Fed. 726, 728 (C.C.D.N.J. 1904).

Several recent consent decrees illustrate the use of trade-marks as a monopoly device. See, e.g., United States v. Switzer Brothers, Inc., 1953 Trade Cas. $\llbracket 67,598$ (N.D. Cal. 1953); United States v. The Permutit Co., 1951 Trade Cas. $\{62,888$ (S.D.N.Y. 1951); United States v. General Electric Co., CCH Trade REg. Rep. (1954 Trade Cás.) $\llbracket 67,714$ (D.N.J. 1954). Cf. Merrimac Hat Corp. v. Crown Overall Mfg. Co., 1950 Trade Cas. $\{62,689$ (S.D.N.Y. 1950) (assertion of trade-mark rights not a violation of Sherman Act).

41. S. Rep. No. 1333, 79th Cong., 2d Sess. 3-4 (1946) ; H. Rep. No. 944, 76th Cong., 
fosters competition. Trade-marks enable buyers to distinguish the goods of competing producers and thus to make an informed choice based on the differences in quality between competitively produced or marketed articles.: This in turn encourages manufacturers to compete in the development of new and better products to maximize consumer satisfaction. But no informed choice is presented to the consumer by allowing international concerns to take advantage of sections 42 and 526. Limiting importation to the American trade-mark registrant only restricts the consumer's choice between sellers of identical goods. This does not encourage quality competition; it merely prohibits price competition.

Although the McGuire and Miller-Tydings Acts authorize resale price maintenance on trade-marked merchandise, ${ }^{43}$ these statutes would not permit American trade-mark registrants to prevent price competition from other importers to the degree allowed by sections 42 and 526. Ordinarily the products of American trade-mark owners related to foreign manufacturers are not in free and open competition with commodities produced or distributed by others, ${ }^{44}$ and therefore fall outside the class of goods covered by the Fair Trade laws. ${ }^{45}$ Moreover, any attempt by importers who own trade-

1st Sess. 2-3 (1939). But see the congressional discussion in connection with $\S 33(b)(7)$ of the Lanham Act, 60 Stat. 438 (1946), 15 U.S.C. $\$ 1115$ (1952), at 92 Co:ic. REc. 7522-25, $7872-74$ (1946).

42. Avrick v. Rockmont Envelope Co., 155 F.2d 568 (10th Cir. 1946); Caron Corp. v. Maison Jeurelle-Seventeen, 26 F. Supp. 560, 563 (S.D.N.Y. 1938) ; Independent Baling Powder Co. v. Boorman, 130 Fed. 726, 723 (C.C.D.N.J. 1904). And consfare Rogers, The Lanham Act and the Social Function of Trade-Marhs, 14 L.1W \& Cosizes. Prop. 173, 175-76 (1949), with Timberg, Trade-Marks, Monopoly and the Restraint of Competition, id. at $323,325-28$.

The judicial stress on informed choice is exemplified by decisions which find no actionable infringement despite consumer confusion when the second producer truthfully describes his product. See, e.g., Canal Co. v. Clark, 13 Wall. (\$0 U.S.) 311 (1871); Dollcraft Co. v. Nancy Ann Storybook Dolls, 94 F. Supp. 1 (N.D. Cal. 1950).

43. Resale price maintenance contracts are only exempted from the price-fixing prohibition of the antitrust laws if authorized for intra-state transactions by state law. 66 StAT. 632, 15 U.S.C. $\S 45$ (1952) (McGuire Act); 50 StAT. 693 (1937), 15 U.S.C. $\S 1$ (1952) (Mililer-Tydings Act). For a compilation of the state statutes, see $2 \mathrm{CCH}$ Trade Reg. Rep. III 10000-15520.10 (1954).

Unless exempted by statute, price fixing is illegal per se under the Sherman Act. United States v. Socony-Vacuum Oil Co., 310 U.S. 150 (1940); United States v. Trenton Potteries Co., 273 U.S. 392 (1927).

44. To a large extent the products are specialty or precision goods having no adequate substitutes in the eyes of American consumers. Thus the decision in the perfume cases is expected to have particular application to the importation of watches and cameras. Department of Justice Press Release, May 28, 1954 (comment by Asst. Att'y' Gen. Barnes). And the complaints against the perfume concerns state that the toilet goods of each defendant possess unique characteristics which distinguish them from all other toilet goods. Complaints cited note 19 supra. But cf. Columbia Records, Inc. v. Goody, 278 App. Div. 401, 105 N.Y.S.2d 659 (1st Dep't 1951); Schill v. Remington Putnam Book Co., 179 Md. 83, 17 A.2d 175 (1941).

45. Only resale price maintenance contracts covering products in "free and open 
marks to fix the resale prices of competing importers would be the kind of horizontal price maintenance which is illegal even under the McGuire and Miller-Tydings Acts. ${ }^{46}$

The history of section 526 also supports the Government's attempt to restrict the use of the current statutory provisions. It was passed to overrule the circuit court decision in the Katzel case, which had held that a trademark could never be infringed by the sale of the genuine product. ${ }^{47}$ The purpose of the section was to protect American purchasers of foreign owned trade-marks from fraud and breaches of contract by the vendors of such marks. ${ }^{48}$ Although there is no such limitation in its wording, ${ }^{40}$ the brief ${ }^{\text {to }}$ legislative history indicates that it was designed solely to protect indepcndont American trade-mark owners. ${ }^{.1}$

competition with commodities of the same general class produced or distributed by others" are exempt from the prohibitions of the antitrust laws. 50 STAT. 693 (1937), 15 U.S.C. $\S 1$ (1952); 66 Star. 632 (1952), 15 U.S.C. § 45 (1952); Eastman Kodak Co. v. Schwarty (Aljan Camera Co.), 133 N.Y.S.2d 908, 917 (Sup. Ct., N.Y. County, 1954); Eastman Kodak Co. v. FTC, 158 F.2d 592 (2d Cir. 1946).

46. Such resale price maintenance would be clearly illegal under the per se rule laid down by the Federal Trade Commission in Eastman Kodak Co., 3 CCHI TrADE REG. REP. I11,527 (9th ed., FTC 1953). And related concerns could not avoid the prohibition against horizontal arrangements by cloaking them as "vertical" agreements even if the more liberal Doubleday rule is applied. Doubleday \& Co., 3 CCH Trade REg. REp. $\| 11,515$ (9th ed., FTC 1953). Fair trade agreements binding competing importers would also constitute the additional restraint of competition required by United States v. McKesson \& Robbins, Inc., 122 F. Supp. 333 (S.D.N.Y. 1954). This is particularly true because the potential importers now excluded from handling the trade-marked products would be direct competitors of the trade-mark owner in the sale to retail outlets. See also Note, 64 YalF L.J. 426 (1954).

47. See, Sturges v. Clark D. Pease, Inc., 48 F.2d 1035, 1037 (2d Cir. 1931); Coty v. Le Blume Import Co., 292 Fed. 264, 268-69 (S.D.N.Y. 1923).

The Court of Appeals handed down its decision on June 8, 1921, and denied a petition for rehearing on June 30, 1921. Bourjois v. Katzel, 275 Fed. 539 (2d Cir. 1921). Section 526 was introduced as an amendment on Aug. 15, 1922, 62 CoNG. Rec. 11383 (1922), and passed on Aug. 19, 1922, id. at 11605.

48. It was stated on the floor that the sole purpose of the section was to prevent the fraud committed against American citizens who had purchased trade-marks from foreigners if the latter then violated their contractual obligations. 62 CoNG. REc. 11603 (1921). There was repeated stress on the rights of the American who had bought the trade-mark from a foreigner. Id. at 11603-04. Furthermore, the fact situation in the Katzel case was misrepresented. It was stated that "the very firm which sold" the trademark rights was now seeking to import the trade-marked product. Id. at 11605.

49. See note 2 supra.

50. The inclusion of $\$ 526$ was a "midnight amendment." 62 Cong. Rec. 11602 (1922). Floor debate in the Senate was limited to ten minutes. Id. at 11585.

51. Thus $\$ 526$ was declared inapplicable if a foreigner registered the trade-mark in the United States and then sold his goods through an agent. 62 CoNG. REc. 11604-05 (1922). And the declared purpose was to protect the Amcrican who bought a forcign mark. Id. at 11603-04. Moreover, the statute was intended to meet the Katzcl fact situation, where the American trade-mark owner was independent of the foreign manufacturer. See notes 12 \& 48 supra. 
The rationale underlying trade-mark protection does not support the exclusion of genuine products by independent American trade-mark owners any more than it supports exclusion by related importers. Consumers are not deceived as to the ultimate source of the commodity whether the American trade-mark owner is an independent distributor of the foreign producer or a related concern. They receive the authentic article made by the originat manufacturer in both cases. ${ }^{52}$ Quality competition based on informed choice cannot be hindered when in fact there is no difference between the merchandise. And competition with tourists and other importers will not harm the reputation of independent American distributors. Their profit expectations may be frustrated. ${ }^{53}$ But the rationale underlying trade-mark protection does not support the enforcement of an absolute import prohibition merely to preserve the profits independent importers expected to derive from monopolizing the American market. ${ }^{54}$

American businessmen would have adequate remedies available to protect their legitimate interests even if they were unable to use sections 42 and 526 to prevent the importation of genuine articles bearing trade-marks similar or identical to their own. If a foreign manufacturer breaks his contractual obligations and tries to compete in the American market, the purchaser of the trade-mark can sue the foreign firm for breach of contract. 65 And if the trade-mark vendor or another foreign concern attempts to market a spurious product within the United States, the American trade-mark owner can invoke sections 42 and 526 or sue for damages arising from trade-mark infringement. ${ }^{56}$ Although the present statutes grant an additional remedy, the trade-mark owner's absolute power of exclusion is too great a threat to consumer interests to justify its added convenience.

52. The early cases holding that a mark on a genuine product does not infringe the mark of the registered owner all involved independent American trade-mark owners. Nevertheless, all held that there was no deception. See cases cited note 11 supro.

53. Sturges v. Clark D. Pease, Inc, 48 F.2d 1035, 1037 (2d Cir. 1931) (dictum). And see text at note 36 supra.

54. Preventing an independent American importer from utilizing $\$ \$ 42 \& 526$ to stop the importation of goods produced by an affiliated manufacturer puts him on a par with domestic manufacturers. Domestic concerns cannot enforce blanket restrictions on the resale of their products. Dr. Miles Medical Co. v. Park \& Sons, 220 U.S. 373 (1911). And they cannot seek to monopolize by preventing purchasers of their merchandise from then competing with them. United States v. Klearflax Linen Looms, 63 F. Supp. 32 (D. Minn. 1945). Cf. FTC v. Beech-Nut Packing Co., 257 U.S. 441 (1922). And see the prohibition of horizontal fair trade price maintenance, note 46 sipro.

55. Apollinaris Co. v. Scherer, 27 Fed. 18, 20 (C.C.S.D.N.Y. 1886) (dictum); Hunyadi Janos Corp. v. Stoeger, 285 Fed. 861, 864 (2d Cir. 1922) (same). The trade-mark oumer can sue for breach of contract either in the United States or abroad. For general discussion of contract enforcement in foreign nations, see 2 RABEL, THE CoNfLICT of LAws: A Courarative Study 357-91 (1947).

56. The trade-mark owner can sue abroad as well as in the United States for damages arising from trade-mark infringement within this country. 2 RAsEl, op. cil. supra note 55, at 295, citing Reichsgericht, July 8, 1930, 129 Entscheidungen des Reichsgerichts in Zivilsachen 385. 
Since section 526 was passed specifically to protect independent American trade-mark owners from the importation of authentic products, ${ }^{, 7}$ courts would find it difficult to hold that an independent trade-mark registrant cannot stop such goods at the border. ${ }^{68}$ However, they should limit the statutes to those situations in which the American trade-mark owner is totally independent of the foreign manufacturer. Congress should go beyond this and amend sections 42 and 526 to make them inapplicable when the American trade-mark owner seeks to prevent the importation of genuine rather than spurious products. ${ }^{59}$ This would be consonant with the basic policies underlying trade-mark law and yet would not deprive American registrants of any remedies necessary to deal with the inequities sections 526 and Katzel sought to correct.

57. See text at notes $47-51$ supra.

58. Even if the utilization of $\$ \S 42$ and 526 by independent concerns is legal in itself, such use is illegal if it is part of a plan to monopolize or to conspire to restrain trade. American Tobacco Co. v. United States, 328 U.S. 781, 809-10 (1946).

59. The legislation introduced in Congress is more limited. It only removes the statutory protection from affiliated concerns, and thus would not prevent a totally independent American concern from stopping genuine goods at the border. See noto 17 supra. 